\title{
Modeling of Wind Power Plant with Doubly-Fed Induction Generator
}

\author{
Ramadoni Syahputra ${ }^{* 1}$, Indah Soesanti ${ }^{2}$ \\ ${ }^{1}$ Department of Electrical Engineering, Universitas Muhammadiyah Yogyakarta \\ Jl. Lingkar Selatan, Tamantirto, Kasihan, Yogyakarta, Indonesia \\ ${ }^{2}$ Department of Electrical Engineering and Information Technology, Faculty of Engineering, \\ Universitas Gadjah Mada \\ Jl. Grafika 2, Kampus UGM, Yogyakarta, Indonesia \\ *Corresponding author, e-mail: ramadoni@umy.ac.id
}

\begin{abstract}
This paper presents the modeling and simulation of wind turbine driven by doubly-fed induction generator which feeds ac power to the distribution network. A stator flux oriented vector control is used for the variable speed doubly-fed induction generator operation. By controlling the generator excitation current the amplitude of the stator EMF is adjusted equal to the amplitude of the grid voltage. To set the generator frequency equal to the grid one, the turbine pitch angle controller accelerates the turbine/generator until it reaches the synchronous speed. The system is modeled and simulated in the Matlab Simulink environment in such a way that it can be suited for modeling of all types of induction generator configurations. The model makes use of rotor reference frame using dynamic vector approach for machine model. The system is also simulated when a fault occurs in $25 \mathrm{kV}$ grid of distribution system. The results of a single line to ground fault and a symmetrical three-phase ground fault is analyzed. The results show that the wind energy conversion system can normally operate in fault conditions
\end{abstract}

Copyright $\odot 2017$ Universitas Muhammadiyah Yogyakarta- All rights reserved.

Keywords: Distributed Generation, Doubly-Fed Induction Generator, Wind Energy Conversion Systems, MATLAB/Simulink

\section{Introduction}

Distributed Generation (DG) is typically defined as small generators, usually less than 30MW, that are connected to transmission or distribution systems [1]-[3]. The emerging new techniques such as small combustion turbines, fuel cells, wind energy, solar energy, and superconducting magnetic energy storage (SMES) make DGs more and more affordable and popular. The government of Indonesia has targeted that DGs from renewable energy resources for up to $5 \%$ of all new generation going online by the year 2025 [4][8]. The target has been emerged because the conventional energy sources are limited and have pollution to the environment [9].

Wind energy is the fastest growing and most promising renewable energy source among them due to economically viable [10]-[14]. Many applications of wind power can be found in a wide power range from a few kilowatts to several megawatts in small scale off-grid standalone systems or large scale grid-connected wind farms. Recently Enercon constructed a wind turbine of 4.5 MW with rotor diameter of 112.8 meters [15]. Due to lack of control on active and reactive power, this type of distributed power generation causes problems in the electrical connected system. So this requires accurate modeling, control and selection of appropriate wind energy conversion system [16][18].

During last two decades, the high penetration of wind turbines in the power system has been closely related to the advancement of the wind turbine technology and the way of how to control. Doubly-fed induction machines are receiving increasing attention for wind energy conversion 
system during such situation. because the main advantage of such machines is that, if the rotor current is governed applying field orientation control-carried out using commercial double sided PWM inverters, decoupled control of stator side active and reactive power results and the power processed by the power converter is only a small fraction of the total system power. So, doubly-fed induction machine with vector control is very attractive to the high performance variable speed drive and generating applications [19]-[21]. With increasing penetration of wind-derived power in interconnected power systems, it has become necessary to model the complete wind energy systems in order to study their impact and also to study wind power plant control. In this paper, an attempt to develop a dynamic model of induction machine which can be simulated as both motoring and generating mode when testing control strategies. Through the model developed in this paper can be used for simulating all types of induction generator configurations [22]. The choice of synchronous rotating reference frame makes it particularly favorable for the simulation of doublyfed configuration in transient conditions. The induction machine is modeled in vectorized form in the synchronous reference frame [23]-[24]. The speed is adjusted by the turbine pitch control to maximize the power generated at a given wind speed. A complete simulation model is developed for such machine under variable speed operation using MATLAB Simulink environment.

\section{Wind Power Plant as a Distributed Generation Unit}

Distributed generations (DGs) sometimes provide the most economical solution to load growth. Low voltages or overloads that are created by load growth may only exist on a circuit for a small number of hours per year. There are many locations within the troubled circuit, or even in neighboring circuits, where a DG may be located to provide control needed to eliminate the low voltage or overload. We assume that it has already been justified that a DG provides the lowest cost solution to a circuit problem and is to be installed to provide the needed control. Placing DGs further out on the circuit can lead to improvements in losses, reliability, or both.

There were several attempts to build large scale wind powered system to generate electrical energy. The first production of electrical energy with wind power was done in 1887 by Charles brush in
Cleveland, Ohio. DC generator was used for power production and was designed to charge the batteries. The induction machine was used at the first time in 1951.

Wind turbines convert the kinetic energy present in the wind into mechanical energy by means of producing torque. Since the energy contained by the wind is in the form of kinetic energy, its magnitude depends on the air density and the wind velocity. The wind power developed by the turbine is given by the equation (1) [8]:

$$
P=\frac{1}{2} C_{P} \rho A V^{3}
$$

where $C_{p}$ is the Power Co-efficient, $\rho$ is the air density in $\mathrm{kg} / \mathrm{m}^{3}, \mathrm{~A}$ is the area of the turbine blades in $\mathrm{m}^{2}$ and $\mathrm{V}$ is the wind velocity in $\mathrm{m} / \mathrm{sec}$. The power coefficient $\mathrm{C}_{\mathrm{p}}$ gives the fraction of the kinetic energy that is converted into mechanical energy by the wind turbine. It is a function of the tip speed ratio $\lambda$ and depends on the blade pitch angle for pitch-controlled turbines. The tip speed ratio may be defined as the ratio of turbine blade linear speed and the wind speed

$$
\lambda=\frac{R \omega}{V}
$$

Substituting (2) in (1), we have:

$$
P=\frac{1}{2} C_{P}(\lambda) \rho A\left(\frac{R}{\lambda}\right)^{3}(\omega)^{3}
$$

The output torque of the wind turbine $\mathrm{T}_{\text {turbine }}$ is calculated by the following equation (4):

$$
P=\frac{1}{2} \rho A C_{P}\left(\frac{V}{\lambda}\right)
$$

where $\mathrm{R}$ is the radius of the wind turbine rotor (m) There is a value of the tip speed ratio at which the power coefficient is maximum. Variable speed turbines can be made to capture this maximum energy in the wind by operating them at a blade speed that gives the optimum tip speed ratio. This may be done by changing the speed of the turbine in proportion to the change in wind speed. Fig. 1 shows how variable speed operation will allow a wind turbine to capture more energy from the wind. As one can see, the maximum power follows a cubic relationship. For variable speed generation, an induction generator is considered attractive due to its flexible rotor speed characteristic in contrast to the constant speed characteristic of synchronous generator. 


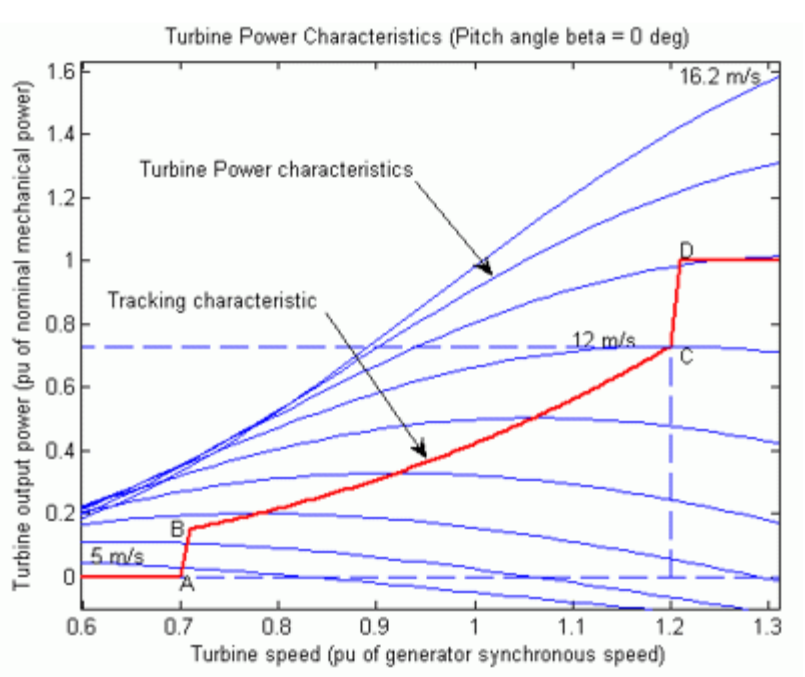

Fig.1. Wind turbine characteristics.

In this study, the rotor is running at subsynchronous speed for wind speeds lower than $10 \mathrm{~m} / \mathrm{s}$ and it is running at a super-synchronous speed for higher wind speeds. The turbine mechanical power as function of turbine speed is displayed in for wind speeds ranging from $5 \mathrm{~m} / \mathrm{s}$ to $16.2 \mathrm{~m} / \mathrm{s}$.

Induction machines are used extensively in the power system as induction motors but are not widely used as generators [9]. Despite their simplicity in construction, they are not preferred as much as synchronous generators. This is mainly due to the defined relationship between the export of $\mathrm{P}$ and absorption of Q. However, induction generators have the benefits of providing large damping torque in the prime mover, which makes it suitable for the application in fixed speed wind turbines. The fixed speed wind turbine uses a squirrel cage induction generator that is coupled to the power system through a connecting transformer. Due to different operating speeds of the wind turbine rotor and generator, a gearbox is used to match these speeds. The generator slip slightly varies with the amount of generated power and is therefore not entirely constant.

General concept of the doubly-fed induction machine is shown in Fig.2. [7]. The mechanical power generated by the wind turbine is transformed into electrical power by an induction generator and is fed into the main grid through the stator and the rotor windings. The rotor winding is connected to the main grid by self-commutated AC/DC converters allowing controlling the slip ring voltage of the induction machine in magnitude and phase angle. In contrast to a conventional, singly-fed induction generator, the electrical power of a doubly-fed induction machine is independent from the speed. Therefore, it is possible to realize a variable speed wind generator allowing adjusting the mechanical speed to the wind speed and hence operating the turbine at the aerodynamically optimal point for a certain wind speed range.

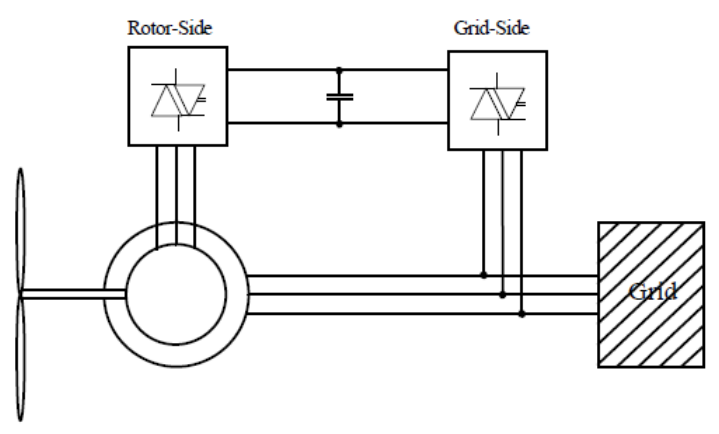

Fig.2. Typical of doubly-fed induction machine [7].

Half of the world's leading wind turbine manufacturers use the doubly fed induction generator systems [10]. This is due to the fact that the power electronic converter only has to handle a fraction $(20 \%-30 \%)$ of the total power, i.e., the slip power. This means that if the speed is in the range $\pm 30 \%$ around the synchronous speed, the converter has a rating of $30 \%$ of the rated turbine power, reducing the losses in the power electronic converter, compared to a system where the converter has to handle the total power. In addition, the cost of the converter becomes lower. The doubly fed induction machine has been used in wind turbines for a long time. In the past, the ACAC converter connected to the rotor consisted of a rectifier and inverter based on thyristor bridges. Nowadays, AC-AC converters are equipped with bidirectional IGBT's, connecting the rotor of the variable speed doubly fed induction generator to the electrical grid.

\section{Modeling of Wind Turbine System}

In this research, physical model of the wind energy conversion system with doubly-fed induction machine connected to grid of distribution system is implemented in Matlab Simulink software. The system models constituting elements of the system separately and also considers interrelationship among different elements within the system, where type and structure of the model is normally dictated by the particular requirements of the analysis, e.g. steady-state, fault studies, etc. Indeed, due to the importance of more realistic 
production of the behavior of doubly-fed induction machine, it is intended to adopt physical model rather than functional model in order to accurately assess performance of doubly-fed induction machine in the event of fault particularly in determining whether or not the generator will trip following a fault. Fig. 3 shows induction machine stator currents and grid-side converter currents, while Fig. 4 shows the wind turbine model. In order to simulate the overall of the system, distribution power system with distributed generation including wind energy conversion system is also illustrated in Fig.5.

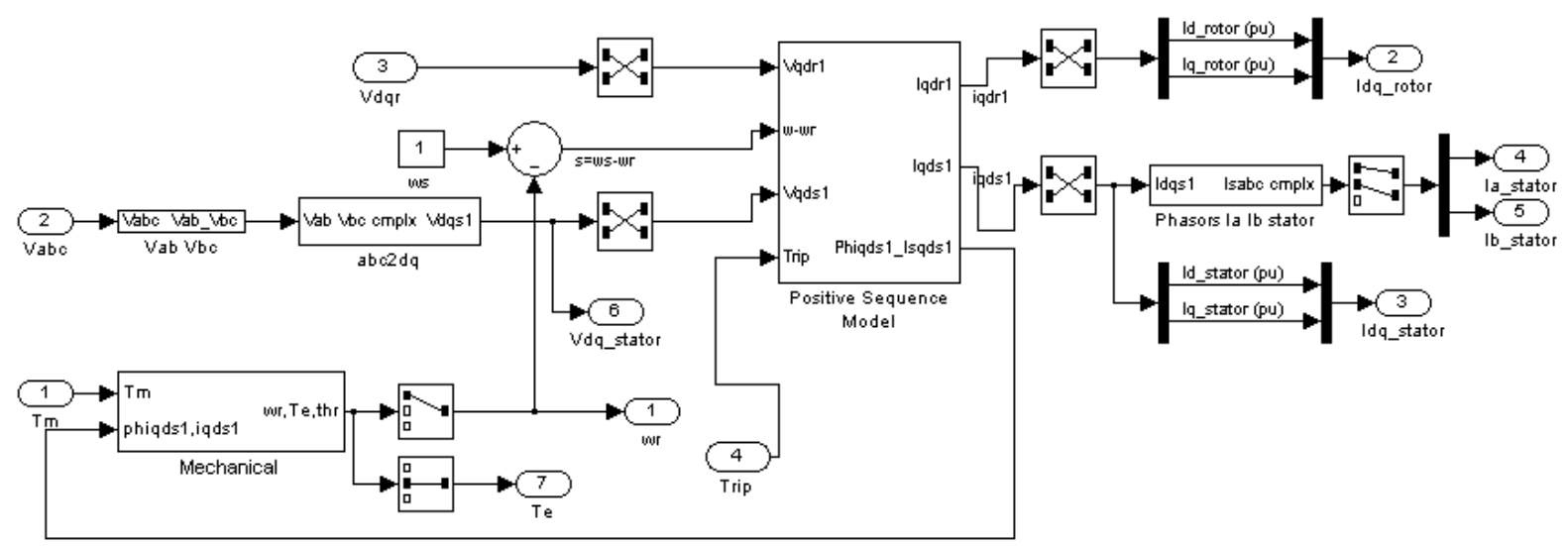

Fig.3. Induction machine stator currents and grid-side converter currents

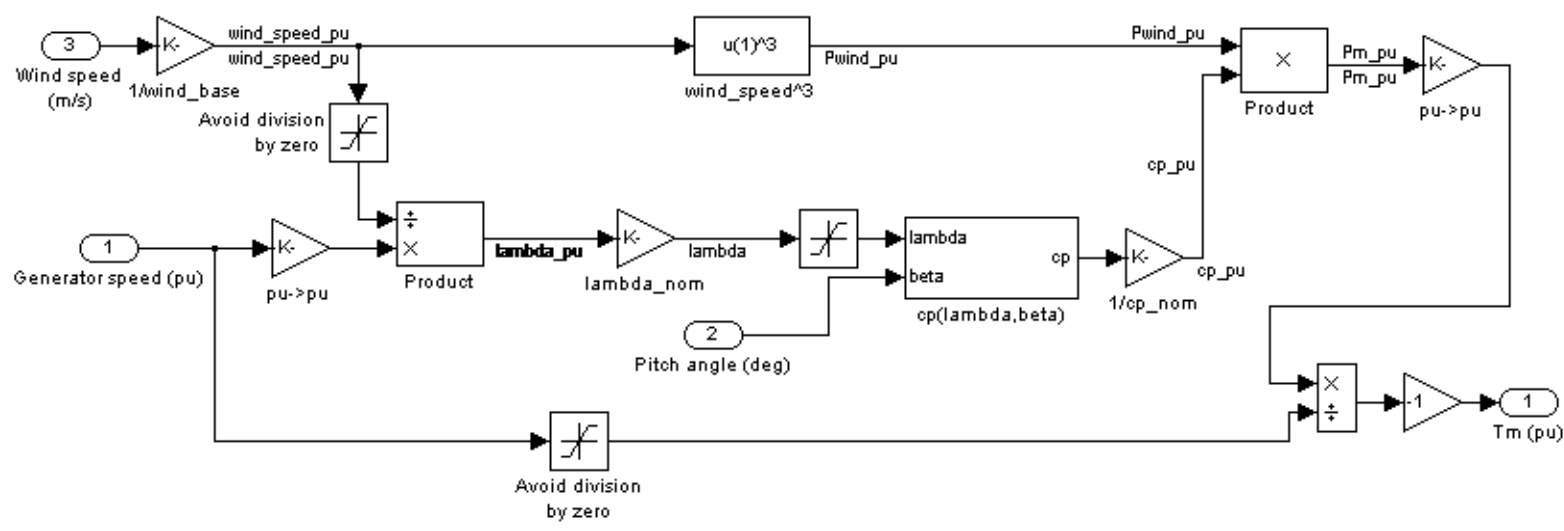

Fig.4. Wind turbine model.

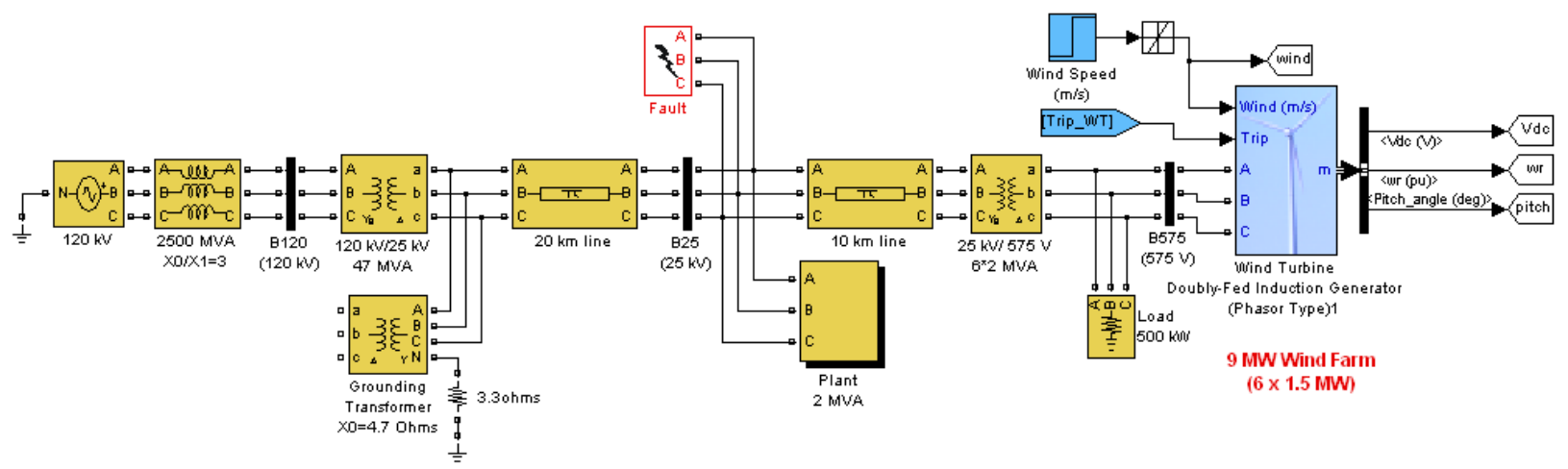

Fig.5. Wind energy connected to a distribution system. 


\section{Research Result}

The presented model is simulated using Matlab Simulink software to investigate the doubly-fed induction machine operation during starting, normal running, and fault conditions. The example described in this section illustrates the steady-state and dynamic performance of a $9 \mathrm{MW}$ wind farm connected to a distribution system. The wind farm consists of six 1.5 MW wind turbines connected to a $25 \mathrm{kV}$ distribution system exporting power to a 120 $\mathrm{kV}$ grid through a $30 \mathrm{~km} 25 \mathrm{kV}$ feeder. A $2300 \mathrm{~V}, 2$ MVA plant consisting of a motor load (1.68 MW induction motor at $0.93 \mathrm{PF}$ ) and of a $200 \mathrm{~kW}$ resistive load is connected on the same feeder at bus B25. A $500 \mathrm{~kW}$ load is also connected on the $575 \mathrm{~V}$ bus of the wind farm. The diagram of this system in Matlab Simulink model is illustrated in Fig.5.

Both the wind turbine and the motor load have a protection system monitoring voltage, current and machine speed. The DC link voltage of the DFIG is also monitored. Wind turbines use a doubly-fed induction machine consisting of a wound rotor induction generator and an AC/DC/AC IGBT-based PWM converter. The stator winding is connected directly to the $60 \mathrm{~Hz}$ grid while the rotor is fed at variable frequency through the $\mathrm{AC} / \mathrm{DC} / \mathrm{AC}$ converter. The doubly-fed induction machine technology allows extracting maximum energy from the wind for low wind speeds by optimizing the turbine speed, while minimizing mechanical stresses on the turbine during gusts of wind. The optimum turbine speed producing maximum mechanical energy for a given wind speed is proportional to the wind speed. Another advantage of the doubly-fed induction machine technology is the ability for power electronic converters to generate or Turbine Data Menu and the Turbine Power Characteristics absorb reactive power, thus eliminating the need for installing capacitor banks as in the case of squirrel-cage induction generators. The terminal voltage will be controlled to a value imposed by the reference voltage $\left(\mathrm{V}_{\text {ref }}=1 \mathrm{pu}\right)$ and the voltage droop $\left(X_{s}=0.02 \mathrm{pu}\right)$.

\section{IV.A. Simulation of Turbine Response to a Change in Wind Speed}

In this section, the turbine response to a change in wind speed is observed. Initially, wind speed is set at $8 \mathrm{~m} / \mathrm{s}$, and then at $\mathrm{t}=5 \mathrm{~s}$, wind speed increases suddenly at $14 \mathrm{~m} / \mathrm{s}$. Fig. 6 shows the waveforms associated with this simulation. At $\mathrm{t}=5 \mathrm{~s}$, the generated active power starts increasing smoothly (together with the turbine speed) to reach its rated value of $9 \mathrm{MW}$ in approximately $15 \mathrm{~s}$. Over that time frame the turbine speed increases from $0.8 \mathrm{pu}$ to $1.21 \mathrm{pu}$.

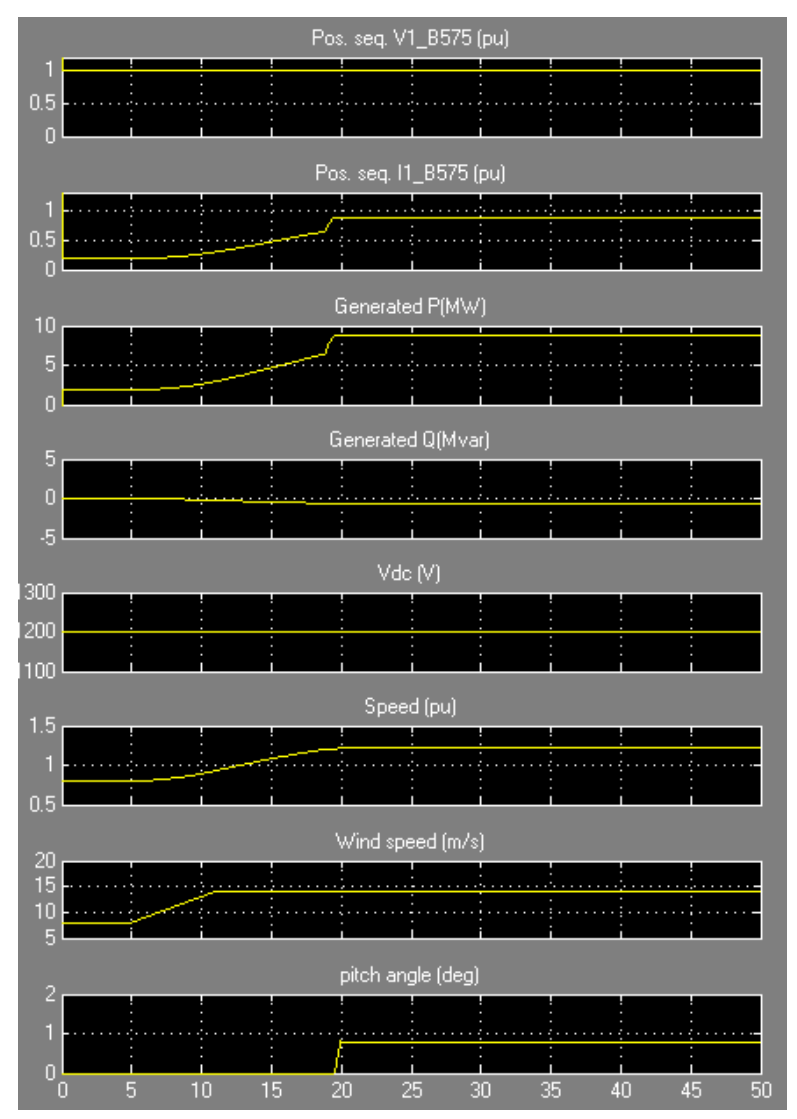

Fig.6. Waveforms for a gust of wind in voltage regulation mode.

Initially, the pitch angle of the turbine blades is zero degree and the turbine operating point follows the red curve of the turbine power characteristics up to point $\mathrm{D}$. Then the pitch angle is increased from 0 deg to $0.76 \mathrm{deg}$ to limit the mechanical power.

The voltage and the generated reactive power is also observed. The reactive power is controlled to maintain a 1 pu voltage. At nominal power, the wind turbine absorbs 0.68 MVar (generated $\mathrm{Q}=-$ $0.68 \mathrm{MVar}$ ) to control voltage at $1 \mathrm{pu}$. If the mode of operation is changed to Varregulation with the Generated reactive power Qref set to zero, the voltage increases to $1.021 \mathrm{pu}$ when the wind turbine generates its nominal power at unity power factor. 


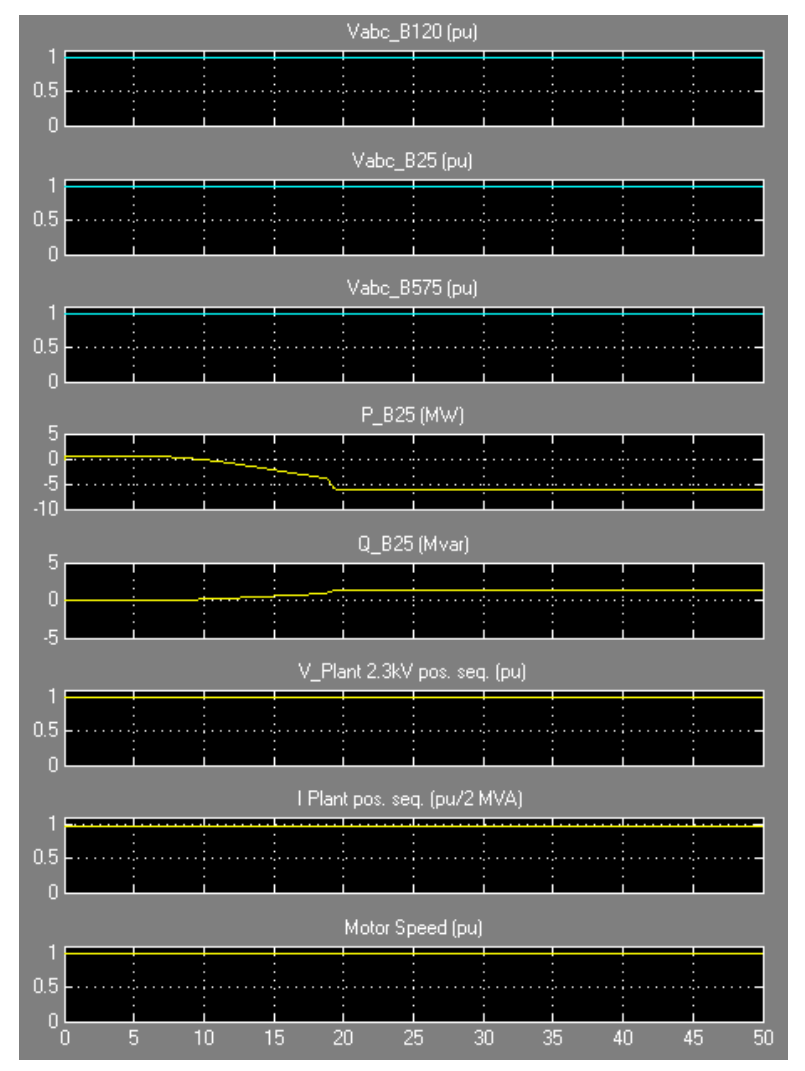

Fig.7. Waveforms for a gust of wind in Var regulation mode.

\section{IV.B. Simulation of Single Line to Ground Fault on the $25 \mathrm{kV}$ System}

In this section, the impact of a voltage sag resulting from a remote fault on the $25 \mathrm{kV}$ system is observed. In this simulation the mode of operation is initially Var regulation with Qref $=0$ and the wind speed is constant at $8 \mathrm{~m} / \mathrm{s}$. A 0.15 pu voltage drop lasting $0.5 \mathrm{~s}$ is programmed, in the $25 \mathrm{kV}$ voltage source menu, to occur at $\mathrm{t}=5 \mathrm{~s}$. The simulation results are illustrated in Fig.8. for voltage regulation mode and Fig.9. for Var regulation mode. The plant voltage and current as well as the motor speed can be observed. Note that the wind farm produces 1.87 MW. At $\mathrm{t}=5 \mathrm{~s}$, the voltage falls below $0.9 \mathrm{pu}$ and at $\mathrm{t}=5.22 \mathrm{~s}$, the protection system trips the plant because an undervoltage lasting more than $0.2 \mathrm{~s}$ has been detected (exceeding protection settings for the Plant subsystem). The plant current falls to zero and motor speed decreases gradually, while the wind farm continues generating at a power level of 1.87 MW. After the plant has tripped, $1.25 \mathrm{MW}$ of power (P_B25 measured at bus B25) is exported to the grid.

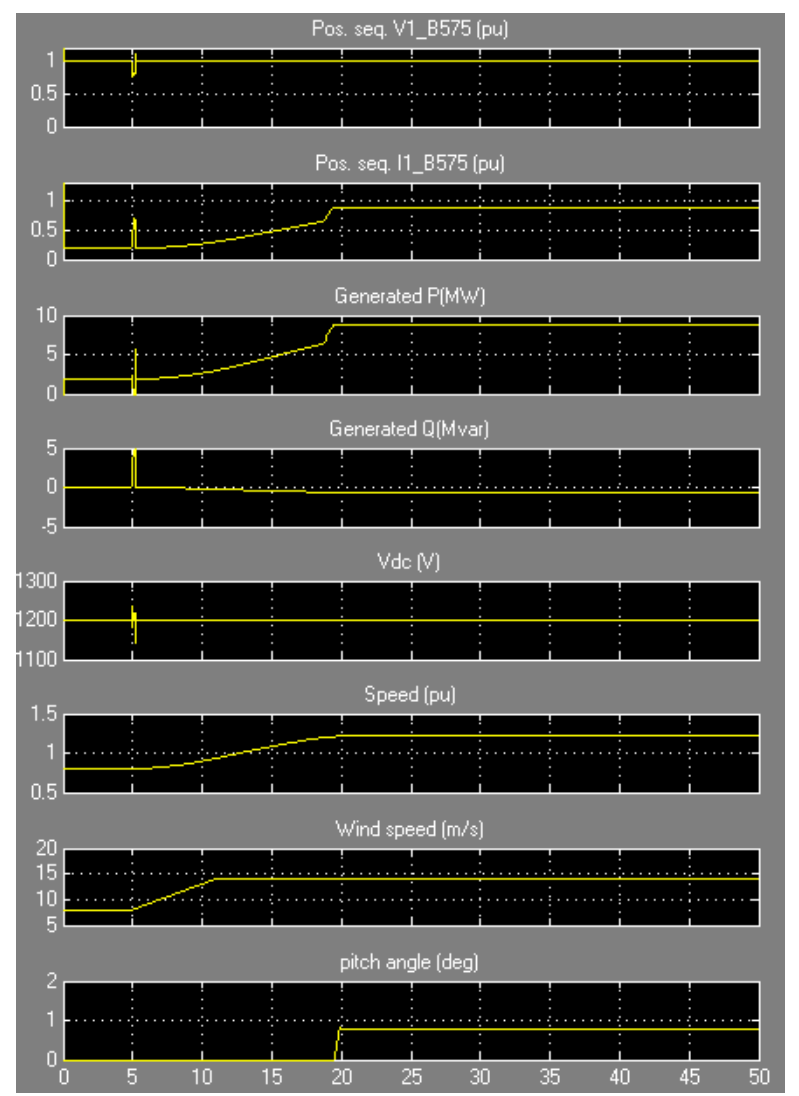

Fig.8. Waveforms for a single line to ground fault on $25 \mathrm{kV}$ system in voltage regulation mode.

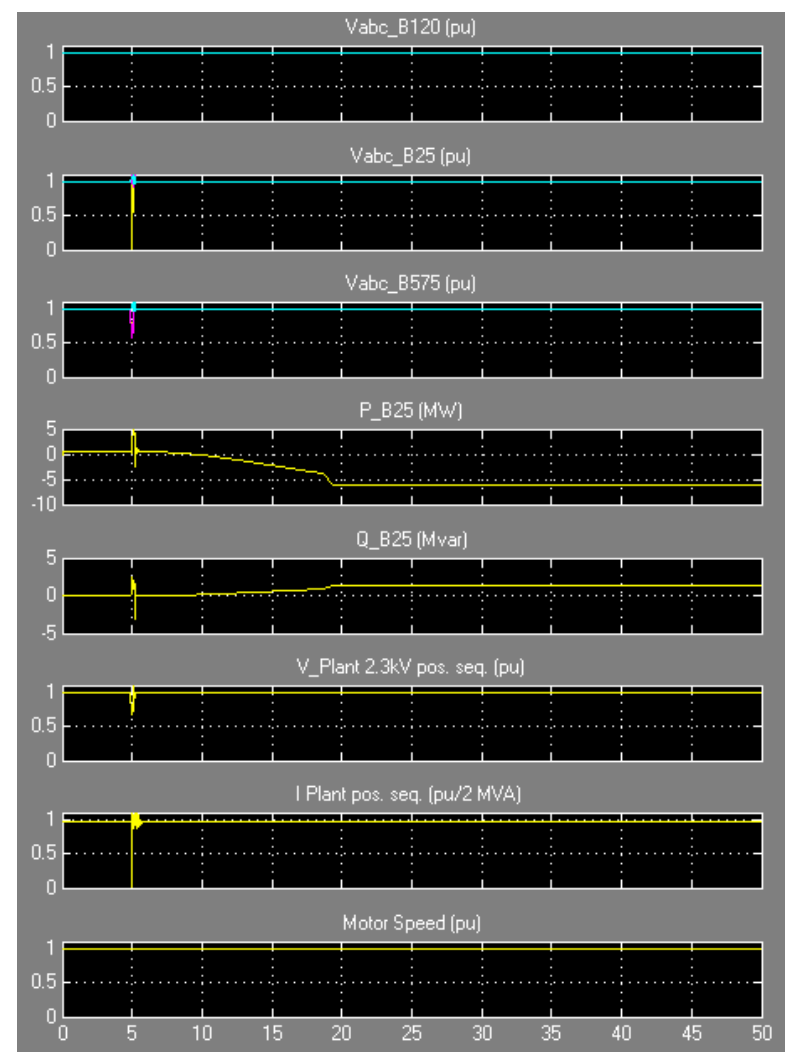

Fig.9. Waveforms for a single line to ground fault on $25 \mathrm{kV}$ system in Var regulation mode. 
As can be seen in Fig.9 that the plant does not trip anymore. This is because the voltage support provided by the 5 Mvar reactive power generated by the wind turbines during the voltage sag keeps the plant voltage above the 0.9 pu protection threshold. The plant voltage during the voltage sag is now 0.93 pu.

\section{IV.C. Simulation of Symmetrical Three Phase Fault on the $25 \mathrm{kV}$ System}

Finally, now observe the impact of a single phase-to-ground fault occurring on the $25 \mathrm{kV}$ line. At $\mathrm{t}=5 \mathrm{~s}$ a 9 cycle $(0.15 \mathrm{~s})$ phase-to-ground fault is applied on phase A at B25 bus. When the wind turbine is in Voltage regulation mode, the positive sequence voltage at wind turbine terminals (V1_B575) drops to 0.8 pu during the fault, which is above the undervoltage protection threshold $(0.75$ pu for a $\mathrm{t}>0.1 \mathrm{~s}$ ).

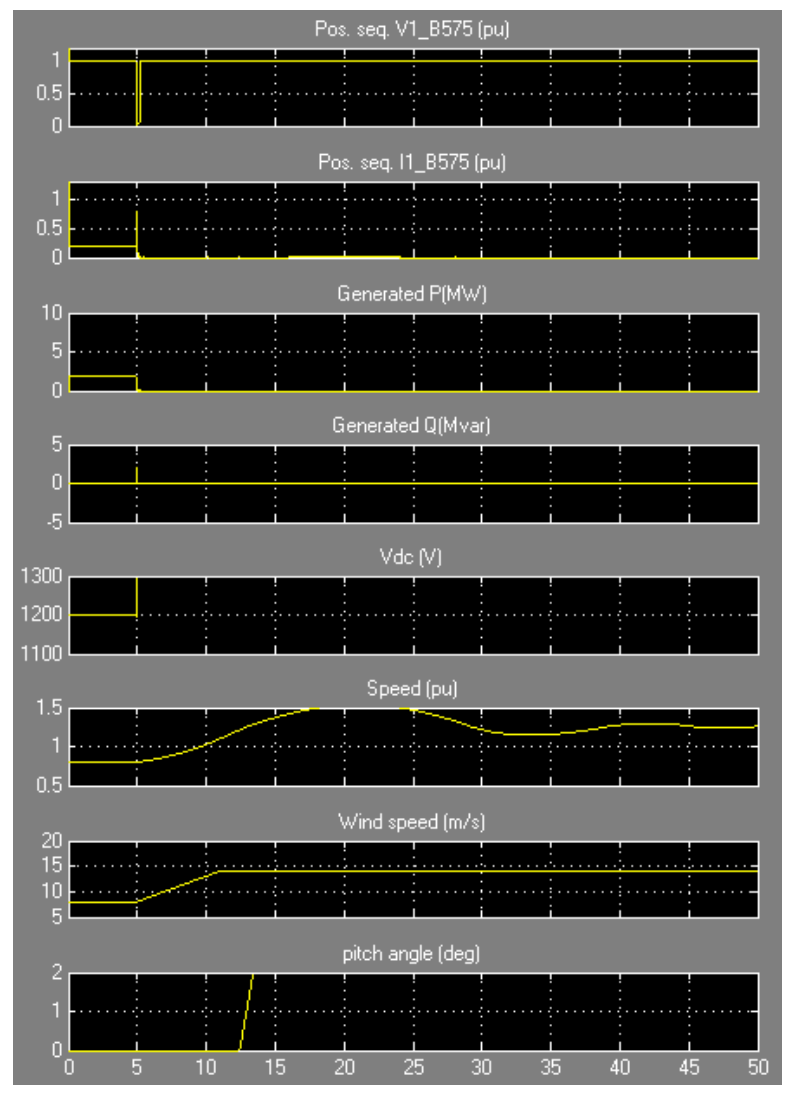

Fig.10. Waveforms for a symmetrical three phase fault on $25 \mathrm{kV}$ system in voltage regulation mode

The wind farm therefore stays in service, as shown in Fig.10. However, if the Var regulation mode is used with Qref $=0$, the voltage drops under
$0.7 \mathrm{pu}$ and the undervoltage protection trips the wind farm. We can now observe that the turbine speed increases. At $\mathrm{t}=40 \mathrm{~s}$ the pitch angle starts to increase to limit the speed, as shown in Fig.11.

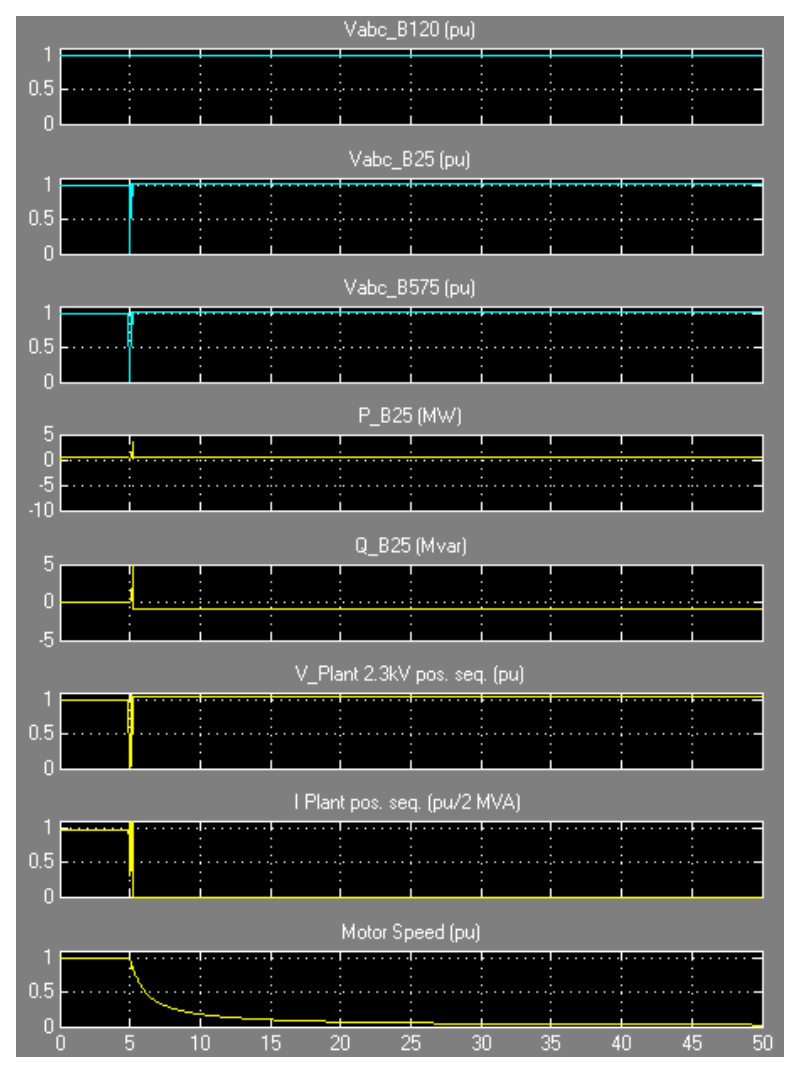

Fig.11. Waveforms for a symmetrical three phase fault on $25 \mathrm{kV}$ system in Var regulation mode.

\section{Conclusion}

This paper has described the modeling and simulation of wind turbine driven by doubly-fed induction machine as a part of distributed generation which feeds ac power to the distribution network. A stator flux oriented vector control is used for the variable speed doubly-fed induction machine operation. By controlling the generator excitation current the amplitude of the stator EMF is adjusted equal to the amplitude of the grid voltage. To set the generator frequency equal to the grid one, the turbine pitch angle controller accelerates the turbine/generator until it reaches the synchronous speed. The system is simulated when a fault occurs in $25 \mathrm{kV}$ grid of distribution system. The results of a single line to ground fault and a symmetrical three phase ground fault show that the wind energy conversion system can normally operate in fault conditions. This condition can be achieved by using the reliable protection system. 


\section{References}

[1] Syahputra, R., Soesanti, I., Ashari, M. (2016). Performance Enhancement of Distribution Network with DG Integration Using Modified PSO Algorithm. Journal of Electrical Systems (JES), 12(1), pp. 1-19.

[2] Syahputra, R., Robandi, I., Ashari, M. (2015). Performance Improvement of Radial Distribution Network with Distributed Generation Integration Using Extended Particle Swarm Optimization Algorithm. International Review of Electrical Engineering (IREE), 10(2). pp. 293-304.

[3] Syahputra, R., Robandi, I., Ashari, M. (2014). Optimization of Distribution Network Configuration with Integration of Distributed Energy Resources Using Extended Fuzzy Multi-objective Method. International Review of Electrical Engineering (IREE), 9(3), pp. 629-639.

[4] Syahputra, R., Robandi, I., Ashari, M. (2015). Reconfiguration of Distribution Network with DER Integration Using PSO Algorithm. TELKOMNIKA, 13(3). pp. 759-766.

[5] Syahputra, R., Soesanti, I. (2016). Design of Automatic Electric Batik Stove for Batik Industry. Journal of Theoretical and Applied Information Technology (JATIT), 87(1), pp. 167-175.

[6] Soesanti, I., Syahputra, R. (2016). Batik Production Process Optimization Using Particle Swarm Optimization Method. Journal of Theoretical and Applied Information Technology (JATIT), 86(2), pp. 272-278.

[7] Syahputra, R., Robandi, I., Ashari, M. (2015). PSO Based Multi-objective Optimization for Reconfiguration of Radial Distribution Network. International Journal of Applied Engineering Research (IJAER), 10(6), pp. 14573-14586.

[8] Syahputra, R., Robandi, I., Ashari, M. (2014). "Optimal Distribution Network Reconfiguration with Penetration of Distributed Energy Resources", Proceeding of 2014 1st International Conference on Information Technology, Computer, and Electrical Engineering (ICITACEE) 2014, UNDIP Semarang, pp. 388 - 393.

[9] Soedibyo, Ashari, M., Syahputra, R. (2014). "Power loss reduction strategy of distribution network with distributed generator integration", Proceeding of 2014 1st International Conference on Information Technology, Computer, and Electrical Engineering (ICITACEE) 2014, UNDIP Semarang, pp. 404 408.

[10] Syahputra, R., Soesanti, I. (2016). DFIG Control Scheme of Wind Power Using ANFIS Method in Electrical Power Grid System. International Journal of Applied Engineering Research (IJAER), 11(7), pp. 5256-5262.

[11] Hossain, M.K., Ali, M.H. (2013). Overview on Maximum Power Point Tracking (MPPT) Techniques for Photovoltaic Power Systems. International Review of Electrical Engineering
(IREE), 8(4). pp. 1363-1378.

[12] Jamal, A., Suripto, S., Syahputra, R. (2015). MultiBand Power System Stabilizer Model for Power Flow Optimization in Order to Improve Power System Stability. Journal of Theoretical and Applied Information Technology (JATIT), 80(1), pp. 116123.

[13] Syahputra, R., Soesanti, I. (2015). Power System Stabilizer model based on Fuzzy-PSO for improving power system stability. 2015 International Conference on Advanced Mechatronics, Intelligent Manufacture, and Industrial Automation (ICAMIMIA), Surabaya, 15-17 Oct. 2015 pp. 121 126.

[14] Syahputra, R. (2017). Distribution Network Optimization Based on Genetic Algorithm. Jurnal Teknologi, Journal of Electrical Technology UMY (JET-UMY), 1(1), pp. 1-9.

[15] Syahputra, R., Soesanti, I. (2016). Application of Green Energy for Batik Production Process. Journal of Theoretical and Applied Information Technology (JATIT), 91(2), pp. 249-256.

[16] Syahputra, R. (2016). Application of Neuro-Fuzzy Method for Prediction of Vehicle Fuel Consumption. Journal of Theoretical and Applied Information Technology (JATIT), 86(1), pp. 138-149.

[17] Syahputra, R., Robandi, I., Ashari, M., (2012), "Reconfiguration of Distribution Network with DG Using Fuzzy Multi-objective Method", International Conference on Innovation, Management and Technology Research (ICIMTR), May 21-22, 2012, Melacca, Malaysia.

[18] Syahputra, R., Wiyagi, R.O., Sudarisman. (2017). Performance Analysis of a Wind Turbine with Permanent Magnet Synchronous Generator. Journal of Theoretical and Applied Information Technology (JATIT), 95(9), pp. 1950-1957.

[19] Jamal, A., Syahputra, R. (2016). Heat Exchanger Control Based on Artificial Intelligence Approach. International Journal of Applied Engineering Research (IJAER), 11(16), pp. 9063-9069.

[20] Syahputra, R., Soesanti, I. (2016). An Optimal Tuning of PSS Using AIS Algorithm for Damping Oscillation of Multi-machine Power System. Journal of Theoretical and Applied Information Technology (JATIT), 94(2), pp. 312-326.

[21] Syahputra, R., Soesanti, I. (2016). Power System Stabilizer Model Using Artificial Immune System for Power System Controlling. International Journal of Applied Engineering Research (IJAER), 11(18), pp. 9269-9278.

[22] Syahputra, R., Soesanti, I. (2017). Application of Fuzzy Multi-Objective Method for Distribution Network Reconfiguration with Integration of Distributed Generation. Journal of Theoretical and Applied Information Technology (JATIT), 95(23), pp. 6668-6677.

[23] Hui, J.C.y., Bakhshai, A., Jain, P.K. (2016). An Energy Management Scheme With Power Limit 
Capability and an Adaptive Maximum Power Point Tracking for Small Standalone PMSG Wind Energy Systems, IEEE Transactions on Power Electronics, 31(7), pp. 4861 - 4875.

[24] Syahputra, R., Suripto, S., Soedibyo, Soesanti, I. (2017). Application of Clonal Selection Immune System Method for Optimization of Distribution Network. Journal of Theoretical and Applied Information Technology (JATIT), 95(15), pp. 36043612 .

\section{Authors' information}

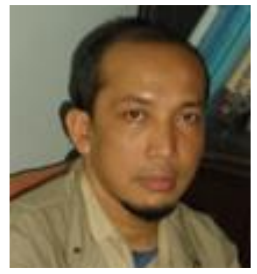

Ramadoni Syahputra received B.Sc. degree from Institut Teknologi Medan in 1998, M.Eng. degree from Department of Electrical Engineering, Universitas Gadjah Mada, Yogyakarta, Indonesia in 2002, and Ph.D degree at the Department of Electrical Engineering, Faculty of Industrial Technology, Institut Teknologi Sepuluh Nopember, Surabaya, Indonesia in 2015.

Dr. Ramadoni Syahputra is a Lecturer in Department of Electrical Engineering, Faculty of Engineering, Universitas Muhammadiyah Yogyakarta, Indonesia. His research interests are in computational of power system, artificial intelligence in power system, power system control, the application of fuzzy logic in power system, optimization, distributed energy resources, and renewable energy.

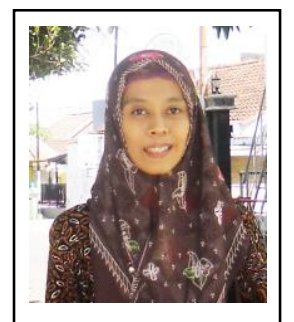

Indah Soesanti was born on June 15 , 1974. She received both M.Eng. and Ph.D. degrees from Department of Electrical Engineering, Gadjah Mada University, Yogyakarta, Indonesia in 2001 and 2011, respectively.

Dr. Indah Soesanti is a Lecturer in the Department of Electrical Engineering and Information Technology, Faculty of Engineering, Universitas Gadjah Mada, Indonesia. Her research interests are in signal processing, image processing, control system, ICT-based system, optimization, artificial intelligence in signal processing pattern classification, and artificial intelligence in control system. 